\title{
GROWTH OF TREES ON THE VIRGINIA TECH CAMPUS IN RESPONSE TO VARIOUS FACTORS
}

\author{
by Richard W. Rhoades' and R. Jay Stipes ${ }^{2}$
}

\begin{abstract}
Soil stresses allegedly repress tree health, growth, and longevity. Such stresses commonly occur on college campuses where soil compaction can result from pedestrian and vehicular traffic. Trees on campuses, as their forest counterparts, also sustain damage from storms and biotic stress agents. We monitored an expression of stress on selected trees on sites judged to be stressful or nonstressful (control) on the Virginia Tech campus. We measured dbh (diameter at breast height) of 9 species and crown diameter of 8 species, from 1993 to 1995. Trunk growth rates differed significantly among species. Five major factors influenced growth of trees: ice damage, percentage of paved area beneath the crown, heart rot, chlorosis, and Dutch elm disease. Almost half $(49 \%)$ of trees were injured physically or manifested disease or rot. We also compared growth rates of trees in 2 groups classified by percentage of paved area beneath the crown, viz. low stress versus presumed stressed sites. Annual rates of trunk growth of campus trees were higher than comparative growth rates of the same species in forests. This was the combined result of several factors, including the fact that open-grown trees, lacking competition in a forest, grow faster. Based on our results, we cannot state conclusively that site stress suppressed growth of trees on campus. Health and longevity variables were not monitored.
\end{abstract}

Trees on both natural and human landscapes are subject to many of the same stresses caused by wind, snow and ice, erosion, poor soil, intertree competition, and drought, as well as many other stresses acting singly or in combination. Landscape trees, however, are exposed to additional stresses such as soil compaction from pedestrian and vehicular traffic and from competition with sidewalks, driveways, roads and buildings, as well as with other trees, shrubs, and turfgrass (Vrecenak et al. 1989; Craul 1994). A satisfactory definition of plant stress is "any factor that results in less than optimum growth rates of plants" (Kozlowski and Pallardy 1997).

Water is generally regarded as the major limiting factor not only for individual plants and crops, but also for the distribution of vegetation over the earth
(Whitlow and Bassuk 1987; Kramer and Boyer 1995). Landscape trees experience frequent water stress caused by several factors. Impervious surfaces and soil compaction retard or prevent recharge of soil waster. Landscape trees experience a heavy heat load, particularly in summer. Surrounding pavement, buildings, and automobiles parked under trees absorb and reradiate large quantities of heat. Heat increases the evaporating power of air and likewise transpiration. These combined effects of water stress and heat load are unusually severe on street trees (Whitlow and Bassuk 1987; Close, Kielbaso et al. 1996; Close, Nguyen et al. 1996).

Tree stress can result in growth suppression, reduction of lifespan, and enhanced susceptibility to certain biotic stressors such as tree pathogens (mostly fungi) and arthropod pests (such as borers), not to mention loss of aesthetics and higher maintenance and replacement costs.

The monitoring and measurement of tree stresses are difficult to perform on large trees over long periods of time, and there are few reports of it. Recent papers reported studies of water stress in street trees in New York City (Whitlow and Bassuk 1987) and comparative growth of sugar maples on urban versus natural sites (Close, Kielbaso et al. 1996; Close, Nguyen et al. 1996). It is generally believed that urban sites are less than optimal for tree growth. Most urban tree managers are concerned about reduction in growth and vigor of trees due to restricted planting area (Vrecenak et al. 1989).

This study used an ecosystem approach. We regarded the landscape of the Virginia Tech campus as an urbanlike ecosystem. We decided to test the hypothesis that poor site quality limits the growth of trees. To do this we set forth 3 objectives: 1 ) to determine growth of various species on a variety of sites, 2) to detect interspecific differences in growth rate, and 3) to compare growth rates of trees on low quality (presumed stressed) sites with those on relatively high-quality (nonstressed) sites. 


\section{METHODS \\ Sampling Procedure}

Trees of 9 species were measured. For 8 species, 2 measurements were made: diameter at breast height $(\mathrm{dbh})$ and crown diameter (CD) by stretching a tape from l edge of the crown to the opposite edge, with 2 measurements made at right angles. For Alaskan white cedar (Chamaecyparis pisifera), only dbh was measured and no estimate was made of percentage of paved area beneath the crown. Attempts were made to measure at least 20 trees of each species. Actual numbers ranged from 15 ( 1 species) to 32 trees per species. From dbh and CD data, diameter growth of trunk and crown were calculated. Total trees measured were 230 , but due to attrition, 200 remained for the final analysis.

In addition to measurements, notes were taken on condition of the site (e.g., portion of crown missing as a result of ice damage, disease symptoms, or lightning damage). An estimate was also made of the percentage of paved area beneath the crown. Diagnoses of disease symptoms were made by Stipes, and estimates of ice damage and the percentage of paved area beneath the crown were made by Rhoades.

Measurements and observations were done in the period after cessation of growth for 3 consecutive years, 1993 to 1995. Soil compaction and $\mathrm{pH}$ were measured with a soil penetrometer and standard $\mathrm{pH}$ paper, respectively. Soil measurements were made during the second week of September 1995. For soil compaction, 2 penetrometer readings were made at the dripline under each of 20 trees-10 on low-traffic areas and 10 on high-traffic areas. Penetrometer readings were made on soil below the organic horizon at a depth of 5 to $10 \mathrm{~cm}$ ( 2 to $4 \mathrm{in}$.). Soil samples for $\mathrm{pH}$ determination were taken from the same sites at a depth of 2 to $10 \mathrm{~cm}(0.8$ to $4 \mathrm{in}$.).

Statistical analyses were done with the Statistical Analysis System (SAS Institute 1990) by personnel of the Statistics Department at Virginia Tech. Data on soil compaction and $\mathrm{pH}$ were compared with paired F-tests (Sokal and Rohlf 1982).

\section{Study Area}

Measurements were made primarily on the campus of Virginia Polytechnic Institute and State University, Blacksburg. Seven trees were measured at nearby Smithfield Plantation, $1.3 \mathrm{~km}(0.8 \mathrm{mi})$ west of the campus. After measuring several sugar maples (Acer saccharum) on areas of high pedestrian traffic on campus, we decided to measure an equivalent number of maples on a site of higher quality.

The climate of Montgomery County is cool, temperate. Data from the Blacksburg weather station are as follows: average annual temperature, $11^{\circ} \mathrm{C}\left(52^{\circ} \mathrm{F}\right)$; January mean temperature, $-1^{\circ} \mathrm{C}\left(30^{\circ} \mathrm{F}\right)$; and July mean temperature, $22^{\circ} \mathrm{C}\left(71.5^{\circ} \mathrm{F}\right)$. Average annual precipitation is $102 \mathrm{~cm}$ (40 in.) with maxima usually in April and September. Average annual frost-free days (above $0^{\circ} \mathrm{C}$ ) are 162 (NOAA 1990).

Soils in and around the campus are urdothents and urban land (Creggar et al. 1985). Urdothents are shallow to deep, somewhat poorly drained soils formed on clayey or loamy residuum of limestone, shale, sandstone or granite, and in fill excavated from these rocks. Slopes range from 0 to $24 \%$. Soil reaction ranges from extremely acid to moderately alkaline.

Soils on nonurban land, principally west of the campus, are classified as Groseclose-Pomplimento loams or silt loams. These soils are well drained and deep. They are formed from the same rocks as urdothents and occur on broad ridgetops and side slopes in the towns of Blacksburg and Christiansburg. The area consists of $45 \%$ urdothents, $30 \%$ urban land, and $25 \%$ other soils.

\section{RESULTS}

Almost half (49\%) of trees measured were injured physically or manifested disease, fungal rot, or chlorosis (Table 1). The most important agent of physical injury was ice damage from 4 ice storms during the second year of the study, of which 3 each deposited between 2.5 and $2.9 \mathrm{~cm}$ ( 1 and $1.1 \mathrm{in}$.) of ice.

American elm (Ulmus americana), sugar maple, black maple (Acer nigrum), and white oak (Quercus alba) sustained the most damage. Although 5 of 20 elms were visibly damaged, all elms suffered some ice breakage. Disease or rot affected $27 \%$ of trees. Dutch elm disease (caused by Ophiostoma novo-ulmi) affected 9 of 20 elms. During the study, 6 elms died of the disease and 1 tree was removed to make room for construction. Seventy-four percent of pin oaks (Q. palustris) were chlorotic, as were 2 northern red oaks (Q. rubra) and 1 flowering dogwood (Cornus florida). Internal decay or top rot affected $10 \%$ of trees. Sugar maple had the greatest amount of heart 
Table 1. Numbers and percentages of trees affected by various factors on the Virginia Tech campus.

\begin{tabular}{|c|c|c|c|c|c|c|c|c|}
\hline & \multicolumn{4}{|c|}{ Abiotic } & \multicolumn{4}{|c|}{ Biotic } \\
\hline & $\begin{array}{l}\text { Total } \\
\text { no. trees }\end{array}$ & $\begin{array}{l}\% \text { paved area } \\
\text { beneath crown }\end{array}$ & $\begin{array}{l}\text { Ice } \\
\text { damage }\end{array}$ & Lightning & $\begin{array}{l}\text { Heart } \\
\text { rot }\end{array}$ & Chlorosis & $\begin{array}{l}\text { Dutch } \\
\text { elm disease }\end{array}$ & $\begin{array}{l}\text { Other } \\
\text { diseases }^{y}\end{array}$ \\
\hline Acer nigrum & 20 & $9(45 \%)$ & $7(35 \%)$ & & $3(15 \%)$ & & & $2(10 \%)$ \\
\hline Chamaecyparis pisifera & 24 & & $4(17 \%)$ & & & & & \\
\hline Cornus florida & 31 & $4(13 \%)$ & $2(6 \%)$ & $1(3 \%)$ & &.$(3 \%)$ & & $2(6 \%)$ \\
\hline Ulmus americana & 13 & $8(62 \%)$ & $5(38 \%)$ & & & & $9(69 \%)$ & \\
\hline Quercus alba & 27 & $4(15 \%)$ & $5(18 \%)$ & & $1(4 \%)$ & & & $1(4 \%)$ \\
\hline Platanus occidentalis & 12 & $6(50 \%)$ & $3(25 \%)$ & & & & & $2(17 \%)$ \\
\hline Acer saccharum & 25 & $16(64 \%)$ & $9(36 \%)$ & & $14(56 \%)$ & & & \\
\hline Quercus palustris & 19 & $15(79 \%)$ & & $1(5 \%)$ & & $14(74 \%)$ & & \\
\hline Quercus rubra & 29 & $23(70 \%)$ & $2(7 \%)$ & $1(3 \%)$ & $2(7 \%)$ & $2(7 \%)$ & & $2(7 \%)$ \\
\hline Totals (\% of total trees) & 200 & $85(43 \%)$ & $37(18 \%)$ & $3(1.5 \%)$ & $20(10 \%)$ & $17(8.5 \%)$ & & $9(4.5 \%)$ \\
\hline
\end{tabular}

${ }^{2}$ Dutch elm disease is omitted from total because the disease affects no other species. yother diseases: anthracnose, bacterial wetwood, swollen butt, Ganoderma decline.

rot (56\%). Two northern red oaks and 3 black maples also showed symptoms of heart rot. In addition, $43 \%$ of trees had more than $10 \%$ paved area beneath the crown.

Annual diameter growth of the trunk ranged from a low of $2.8 \mathrm{~mm}(0.08 \mathrm{in}$.) for Alaskan white cedar to a high of $13.4 \mathrm{~mm}(0.53 \mathrm{in}$.) for northern red oak (Table 2). All trunk growth rates are significantly different from zero (t-test, Alaskan white cedar, $P \leq 0.05$; all others, $P \leq 0.01$ ). The lowest value for crown growth was for American elm; the highest was for northern red oak. Effects of ice damage are manifested in the negative rates of crown growth for 3 species (Table 2).

For crown growth, values of only 3 species were significantly different from zero (sugar maple at $P \leq$ 0.05 , sycamore and northern red oak at $P \leq 0.01$ ).

Results of a l-way analysis of variance (ANOVA) indicated significant differences among species in trunk growth $(P \leq 0.0004)$ and crown growth $(P \leq$ 0.0001 ). In lieu of a multiple range test, we performed a series of 1-factor ANOVAs to determine significant contrasts between pairs of species in trunk and crown growth. Northern red oak had consistently higher trunk growth than 3 other species and consistently higher crown growth than 2 additional species (Table 3). In addition, sugar maple and sycamore (Platanus occidentalis) had significantly greater crown growth than black maple. Out of 36 paired contrasts for trunk growth and 28 contrasts for crown growth, only 11 were significant.
Because the 1-way ANOVA indicated significant differences among species, we decided to compare trees in 2 groups (presumed stressed versus relatively nonstressed trees). First we performed correlation analysis by species to test for association of trunk and crown growth with the percentage of paved area beneath the crown. Growth rates for all species were strongly correlated with percentage of paved area $(r=1.0000)$.

On the basis of these results, we divided the trees into 2 groups: stressed trees with $>10 \%$ paved area beneath the crown, and nonstressed trees with $\leq 10 \%$ paved area beneath the crown. Numbers of trees in each group vary by species (Table 4). A 2-way ANOVA indicated possible significant differences among species for trunk growth $(P \leq 0.14)$ and crown growth $(P \leq 0.07)$ and highly significant differences between groups for trunk growth $(P \leq 0.0004)$ and crown growth $(P \leq 0.0001)$.

Mean trunk growth was higher on presumed stressed sites ( $9.6 \mathrm{~mm}$ [0.38 in.]) than on nonstressed sites $(8.0 \mathrm{~mm}$ [0.31 in.]); however, mean crown growth was greater on nonstressed sites $(0.08 \mathrm{~m}$ [0.3 ft] versus $0.015 \mathrm{~m}[0.05 \mathrm{ft}]$ ).

We also compared 7 northern red oaks that were growing closely enough to compete with 7 red oaks randomly chosen from the remaining trees in the sample. A t-test indicated no significant differences in trunk or crown growth between the two groups.

Soil $\mathrm{pH}$ was significantly higher $(P \leq 0.001)$ on the presumed stress sites ( $\mathrm{pH}$ 6.2) than on the 
Table 2. Annual diameter growth of trunk and crown, 1993 to 1995 (means and their standard errors).

\begin{tabular}{lllllll}
\hline & \multicolumn{2}{c}{ Trunk } & & \multicolumn{2}{c}{ Crown } \\
\cline { 2 - 3 } & \multicolumn{2}{c}{ Growth } & & \multicolumn{2}{c}{ Growth } & \\
& $(\mathrm{mm})$ & s.e. & & $(\mathrm{m})$ & s.e. & $\mathrm{N}$ \\
\hline Chamaecyparis pisifera & 2.8 & 1.18 & & & 24 \\
Cornus florida & 3.6 & 0.56 & 0.11 & 0.087 & 31 \\
Acer nigrum & 3.8 & 0.84 & -0.48 & 0.203 & 20 \\
Ulmus americana & 7.6 & 1.92 & -0.52 & 0.273 & 13 \\
Quercus alba & 9.9 & 2.58 & -0.19 & 0.254 & 27 \\
Acer saccharum & 10.2 & 2.89 & 0.33 & 0.138 & 25 \\
Platanus occidentalis & 10.5 & 2.10 & 0.43 & 0.111 & 12 \\
Quercus palustris & 11.8 & 1.49 & 0.016 & 0.118 & 19 \\
Quercus rubra & 13.4 & 2.20 & 0.51 & 0.094 & 29 \\
\hline
\end{tabular}

Table 3. Contrasts between pairs of species, by 1 factor ANOVA, in diameter growth of trunk and crown. (Means followed by the same letter are not significantly different at $P \leq 0.0001 .^{z}$ )

\begin{tabular}{llll}
\hline & \multicolumn{4}{c}{ Trunk growth $(\mathrm{mm})$} \\
\hline $\begin{array}{l}\text { Chamaecyparis } \\
\text { pisifera }\end{array}$ & $\begin{array}{l}\text { Cornus } \\
\text { florida }\end{array}$ & $\begin{array}{l}\text { Acer } \\
\text { nigrum }\end{array}$ & $\begin{array}{l}\text { Quercus } \\
\text { rubra }\end{array}$ \\
\hline $2.8 \mathrm{a}$ & $3.6 \mathrm{a}$ & $3.8 \mathrm{a}$ & $13.4 \mathrm{~b}$
\end{tabular}

Crown growth $(\mathrm{m})$

\begin{tabular}{llllll}
\hline Ulmus & $\begin{array}{l}\text { Acer } \\
\text { americana }\end{array}$ & $\begin{array}{l}\text { Quercus } \\
\text { nigrum }\end{array}$ alba & $\begin{array}{l}\text { Acer } \\
\text { saccharum }\end{array}$ & $\begin{array}{l}\text { Platanus } \\
\text { occidentalis }\end{array}$ & $\begin{array}{l}\text { Quercus } \\
\text { rubra }\end{array}$ \\
\hline$-0.52 \mathrm{a}$ & $-0.48 \mathrm{a}$ & $-0.19 \mathrm{a}$ & $0.3 \mathrm{~b}$ & $0.43 \mathrm{~b}$ & $0.51 \mathrm{c}$ \\
\hline
\end{tabular}

${ }^{2}$ These were the only significant differences between pairs of species.

nonstressed sites ( $\mathrm{pH}$ 5.2). Soil resistance, however, was identical $(0.3 \mathrm{MPa})$ at the two kinds of sites.

\section{DISCUSSION}

Ice damaged more trees during the study than any other factor. Three ice storms occurred in March 1994, and the damage was especially severe on American elm. This species has fine and brittle branches, so it is very susceptible to ice damage. In Virginia, American elm begins growth between the last week in February and the third week in March. The ice storms occurred just as the elms were starting spring growth. Breakage of limbs opened pathways for infection by Dutch elm disease.

Heart rot was second to ice damage as an injurious factor. As previously stated, sugar maple had the largest amount of heart rot. This species is quite susceptible to internal decay caused by a variety of fungi (Burns and Honkala 1990b).
Table 4. Numbers of trees in each stress group classified by paved area beneath the crown.

\begin{tabular}{lcll}
\hline & $\begin{array}{l}\text { S10\% of } \\
\text { paved area }\end{array}$ & $\begin{array}{l}>10 \% \\
\text { of paved area }\end{array}$ & N \\
\hline Acer nigrum & 9 & 11 & 20 \\
Cornus florida & 4 & 27 & 31 \\
Ulmus americana & 7 & 6 & 13 \\
Quercus palustris & 15 & 4 & 19 \\
Quercus rubra & 23 & 6 & 29 \\
Acer saccharum & 16 & 9 & 25 \\
Platanus occidentalis & 5 & 6 & 12 \\
Quercus alba & 23 & 4 & 27 \\
\hline
\end{tabular}

Ornamental pin oaks on alkaline soils are chlorotic. While it was previously thought to be the result of iron deficiency, the condition actually involves reduced foliar concentrations of iron, manganese or zinc, often with increased foliar concentrations of one or more macronutrients ( $\mathrm{P}, \mathrm{K}$, or $\mathrm{Mg}$ ) (Burns and Honkala 1990b).

Soil pH under several pin oaks on the campus averaged 6.2, within the range of $\mathrm{pH}$ for GroseclosePomplimento soils (3.6 to 6.5) (Creggar et al. 1985). The chlorotic pin oaks were growing on sites where fill containing limestone fragments could be in the soil. These sites were on narrow ( 1 to $1.5 \mathrm{~m} \mathrm{[3.3} \mathrm{to} 4.9 \mathrm{ft}$ ] wide) islands in parking lots or in raised concrete planters about $3 \mathrm{~m}(9.8 \mathrm{ft})$ square. On these sites, root mass is limited, which can also induce chlorosis.

The annual rates of trunk growth for trees in this study were higher than similar rates of trees on natural sites (Burns and Honkala 1990a, 1990b). This is contrary to findings of Close, Nguyen et al. (1996), who determined that terminal growth of sugar maple was significantly higher in a woodlot compared with campus street trees.

Growth of trees can be limited by several factors. Restricted planting area is a major factor. The soil is often covered with pavement, and other plants, trees, shrubs, and turfgrass can compete with landscape trees (Vrecenak et al. 1989). However, the landscape of the Virginia Tech campus is not as stressful for trees as we had supposed. First, 5 species had higher growth rates on presumed stressed sites than on low-stress sites. Second, trunk growth of all species measured on the Virginia Tech campus was higher than published rates of those species in forests (Burns and Honkala 1990a, 1990b). 
There are several possible causes of these results. In forests, the amount of light available to the lower canopy is low because of shading by nearby trees. Light intensity also decreases rapidly downward in tree crowns. Open-grown trees receive more light in the lower canopy (Kozlowski and Pallardy 1997).

Trees growing in isolation on a landscape are similar to released trees in a thinned forest stand. In a thinned stand of trees, the amount of growing space for roots and crowns of the remaining trees increases. Rates of growth increase because more light is available, as well as water and mineral nutrients. The result is an increase in photosynthetic rates and production of hormonal regulators. After a stand has been thinned, released trees respond by increased branch size and survival (Kramer and Kozlowski 1979).

Thinning produces a more tapered trunk because of an increase in cambial activity and radial growth toward the base of the tree rather than the crown. The redistribution of growth may be deceptive because the increase in $\mathrm{dbh}$ after thinning may give an erroneous impression about the actual increase in volume (Kramer and Kozlowski 1979).

Because small trees grow faster than large trees, our data on trunk growth could be biased by inclusion of small trees in the sample, However, this was not a factor in this study. Excluding flowering dogwood, only $14(8 \%)$ of the remaining trees were small, less than $30 \mathrm{~cm}$ (11.8 in.) dbh. Lack of competition with neighboring trees may also be a reason for the relatively high growth rates of trees in our sample. However, a comparison between 2 groups of northern red oaks (competing versus noncompeting) tended to rule out this factor for that species, but not necessarily for other species.

An additional reason for the results may involve the extensive turfgrass fertilization program on the Virginia Tech campus plus adequate to aboveaverage precipitation during the period of study. Abundant minerals and water tend to shift root:shoot ratios toward more shoot growth (Kozlowski and Pallardy 1997).

Although some species and some individual trees probably experienced suppression of growth, much of it was due to factors unrelated to site characteristics. That is, ice damage and Dutch elm disease affected $25 \%$ of the trees. Heart rot affected sugar maple most, but as previously noted, this species is susceptible to heart rot. The only condition we can attribute to site stress unconditionally is chlorosis of pin oak.

Apparently, a stressed site, based on our criteria, may actually be a suitable site for tree growth. Based on our statistical results, we were forced to reject the hypothesis that presumed site stress suppressed growth of trees on the Virginia Tech campus.

\section{LITERATURE CITED}

Burns, R.M., and B.H. Honkala (Tech Coord.). 1990a. Silvics of North America, Volume 1, Conifers. U.S Dept. Agric. Hdbk. 654. Washington, DC. 675 pp.

Burns, R.M., and B.H. Honkala (Tech. Coord.). 1990b. Silvics of North America, Volume 2, Hardwoods. U.S. Dept. Agric. Hdbk. 654. Washington, DC. 877 pp.

Craul, P.J. 1994. Soil compaction on heavily used sites. J. Arboric. 20:69-74.

Close, R.E., J.J. Kielbaso, P.V. Nguyen, and R.E. Schutski. 1996. Urban vs, natural sugar maple growth: Water relations. J. Arboric. 22:187-192.

Close, R.E., P.V. Nguyen, and J.J. Kielbaso. 1996. Urban vs. natural sugar maple growth: Stress symptoms and phenology in relation to site characteristics. J. Arboric. 22:144-150.

Creggar, W.H., H.C. Hudson, and H.C. Porter, 1985. Soil survey of Montgomery County, Virginia, U.S. Dept. Agric., Soil Conserv. Serv. 256 pp.

Kozlowski, T.T., and S.G. Pallardy. 1997. Physiology of Woody Plants. Academic Press, San Diego, CA. 411 pp.

Kramer, P.J., and J.S. Boyer. 1995. Water Relations of Plants and Soils. Academic Press, San Diego, CA. 495 pp.

Kramer, PJ., and T.T. Kozlowski. 1979. Physiology of Plants. Academic Press, New York, NY. 811 pp.

National Oceanic and Atmospheric Administration (NOAA). 1990. Climatological Data Annual Summary, Virginia. Vol. 100, No. 13. Washington, DC.

SAS Institute, Inc. 1990. SASISIAT User's Guide. Version 6. 4th ed. SAS Institute, Inc. Cary, NC.

Sokal, R.R., and FJ. Rohlf. 1982. Biometry. 2nd ed. W.H. Freeman and Company, San Francisco, CA. 777 pp.

Vrecenak, A.J., M.C. Vodak, and L.E. Fleming. 1989. The influence of site factors on the growth of urban trees. J. Arboric. 15:206-209.

Whitlow, T.H., and N.L. Bassuk. 1987. Trees in difficult sites. J. Arboric. 13:10-17. 
Acknowledgements. We thank the following members of the Statistics Department at Virginia Polytechnic Institute and State University for help with the statistical analysis: Dr. Robert Foutz and graduate students Michelle Riley and Peter Ammermann.

\section{${ }^{1}$ Plant Ecologist}

611 Rose Avenue

Blacksburg, VA 24060

\section{${ }^{2 *}$ Professor of Plant Pathology \\ Virginia Tech \\ Blacksburg, VA 24061-0331}

\section{*Corresponding author}

Résumé. Lès sols perturbés, à ce que l'on prétend, font diminuer la santé, la croissance et la longévité des arbres. Ces types de stress se retrouvent fréquemment sur les campus de collèges où le sol est compacté par la circulation des piétons et des véhicules. Les arbres subissent également des dommages par des tempêtes et des agents biotiques pathogènes. Nous avons quantifié l'expression de ces stress sur des arbres de sites jugés stressants et d'autres non stressants (témoins) sur le Campus de Virginia Tech. Nous avons mesuré le DHP (diamètre à hauteur de poitrine) de neuf espèces et la largeur de cime de huit espèces de 1993 à 1995. Le taux de croissance en diamètre différait significativement entre les espèces. Le chêne rouge (Quercus nubra) avait le plus fort taux de croissance et le cyprès porte-pois (Chamaecyparis pisifera) le plus faible. Cinq facteurs majeurs influençaient la croissance des arbres: dommages par le verglas, pourcentage de racines pavées, carie de coeur, chlorose et maladie hollandaise de l'orme. Pratiquement la moitié (49\%) des arbres étaient blessés physiquement ou manifestaient des symptômes de maladie ou de carie. Le verglas a endommagé $20 \%$ des arbres, la carie de coeur $10 \%$ et les chloroses $8 \%$. La maladie hollandaise de l'orme a affecté 9 des 20 ormes d'Amérique (Ulmus americana) et 6 en sont mort. Nous avons aussi comparé le taux de croissance des arbres entre deux groupes classifiés selon le pourcentage de système racinaire pavé. La croissance moyenne en diamètre était plus élevée mais celle de la cime plus faible sur les sites stressés. Les taux de croissance annuels en diamètre étaient supérieurs sur les arbres du campus que pour les mêmes espèces en milieu forestier. Ceci est probablement l'effet des résultats combinés de la fertilisation des pelouses et de précipitations adéquates durant la période d'étude. En se basant sur ces résultats, nous ne pouvons conclure que les sites stressés font diminuer la croissance des arbres sur le campus.

Zusammenfassung. Stress im Boden unterdrückt angeblich die Baumgesundheit, Wachstum und die Langlebigkeit. Solche Stresse treten gewöhnlich auf Universitätsgeländen auf, wo durch Fußgänger und Fahrzeugverkehr Bodenverdichtungen entstehen. Die Bäume erfahren auch Schaden durch Sturm und biotische Stressfaktoren. Wir überwachten die Anzeichen von Stress an ausgewählten Bäumen auf Standorten auf dem Campus der Technischen Uni Virginia, die als besonders belastet bzw nicht belastet (Kontrolle) waren. Von 1993 bis 1995 maßen wir den BHD von neun Arten und den Kronendurchmesser von sechs Baumarten. Unter den Arten gab es signifikante Unterschiede bei der Wachstumsrate des Durchmessers. Die Roteiche (Quercus rubra) hatte die höchsten Wachstumsraten und die Alaska-Scheinzypresse (Chamaecyparis pisifera) die niedrigsten. Das Wachstum von Bäumen wird durch fünf Hauptfaktoren beeinflußt : Eisbruch, versiegelte Wurzelräume, Kernfäule, Chlorose und Holländische Ulmenkrankheit. Fast die Hälfte (49\%) aller Bäume sind physikalish geschädigt oder von Krankheit und Fäule betroffen. Eis schädigt $20 \%$ der Bäume, kernfäule $10 \%$ und Chlorose $8 \%$. Die Holländische Ulmenkrankheit betraf 9 von 20 Amerikanischen Ulmen (Ulmus americana) und sechs davon starben. Wir verglichen auch die Wachstumsrate von Bäumen, die in zwei Gruppen je nach dem Prozentsatz an versiegelter Wurzelfläche eingeteilt waren. Der mittlere Dickenzuwachs war höher als vergleichbare Wachstumsraten bei Bäumen gleicher Art, die im Wald stehen. Das war wahrscheinlich der kombinierte Effekt aus Grünlanddüngung und adäquater Regenmenge während des Beobachtungszeitraums. Basierend auf diesen Ergebnissen können wir nithct abschließend behaupten, das der Standortstress das Wachstum der Bäume auf dem Campus underdrückt.

Resumen. Se discute cómo el estrés en el suelo reprime la salud del árbol, el crecimiento y la longevidad. Tal estrés comúnmente ocurre en campus colegiales, donde la compactación del suelo resulta del tráfico peatonal y vehicular. Los árboles reciben también daños por tormentas y agentes bióticos de estrés. Se monitoreó la expresión del estrés en árboles seleccionados en sitios juzgados como estresados y no estresados (control) en el campus del Tecnológico de Virginia. Se midió dhb (diámetro a la altura del pecho) de 9 especies y diámetro de la copa de 8 especies, de 1993 a 1995. Las tasas de crecimiento en diámetro difieren significativamente entre especies. El roble rojo norteño (Quercus rubra) tuvo la más alta tasa de crecimiento y Chamaecyparis de Alaska (Chamaecyparis 
pisifera) la más baja. Los 5 factores principales que influyen en el crecimiento de los árboles son: daño por hielo, por ciento de pavimento sobre las raíces, pudrición de la raíz, clorosis y enfermedad holandesa del olmo. Casi la mitad (49\%) de los árboles estuvieron dañados físicamente o manifestaron enfermedad o descomposición. El hielo dañó al 20\% de los árboles, la pudrición de la raíz al 10\%, y la clorosis al $8 \%$. La enfermedad holandesa del olmo afectó 9 de 20 olmos americanos (Ulmus americana) y 6 murieron. Se compararon también tasas de crecimiento de los árboles en dos grupos clasificados en por ciento de área radical cubierta por pavimento. El promedio de crecimiento en diámetro fue mayor, pero el crecimiento de la copa fue más bajo en sitios estresados. Las tasas anuales de crecimiento en diámetro de los árboles del campus fueron mayores que los de la misma especie que crecen en el bosque. Esto fue probablemente el resultado combinado de la fertilización del pasto y la lluvia adecuada durante el período de estudio. Con base en estos resultados se puede concluir que los sitios estresados reprimen el crecimiento de los árboles en campus colegiales. 